Progestasert is not an approved appliance in the Drug Tariff and is therefore only prescribable as a private prescription, which will cost the patient over £33. Pharmacists will not therefore be reimbursed for any FP10 prescription should they dispense this product.

H MCNuLTY Principal Pharmacis Regional Drug Information Service Bristol Royal Infirmary,
Bristol

\section{Arthroscopy of the knee}

SIR,-Dr D J Stoker in his comments (29 January, p 287) on Mr Adrian Henry's article on arthroscopy of the knee (8 January, $p$ 87) rightly points out that arthrography has a part to play in the management of intra-articular disorders of the knee. However, his statement that arthrography is the investigation of first choice in the diagnosis of meniscal injury cannot be allowed to go unchallenged.

The great advantage of arthroscopy over arthrography is that it allows the surgeon who is going to operate on the joint to assess the situation for himself. From the patient's point of view both the investigation and operation if it is required, are one event rather than two separate incidents. Because arthroscopy is carried out under anaesthetic the surgeon may examine the joint with full relaxation and further valuable diagnostic information may be obtained. Finally, in skilful hands the arthroscope allows assessment of meniscal disorder to be as complete as anything that can be achieved by a skilled arthrographer.

While I agree that enthusiasm for one procedure should not blind us to the virtues of the other, it cannot be disputed that, from the point of view of the surgeon, to be able to see the meniscus and its abnormality is preferable to the view of an $x$-ray film taken by someone else.

S C GallanNaugh

St George's Hospital,

London SW 1

\section{Carboxyhaemoglobin in lead workers}

SIR,-In lead poisoning there is evidence of increased destruction of erythrocytes in that the red cell survival time is shortened. ${ }^{12}$ However, the mechanism of this is not clear, for the osmotic fragility appears to be little changed ${ }^{34}$ and the claim that the mechanical fragility of these cells is increased ${ }^{5}$ has been challenged. ${ }^{6}$ ?

In degradation of haemoglobin the porphyrin ring is opened at the methine bridge and one mole of carbon monoxide is formed from each mole of haemoglobin broken down. We have investigated the carboxyhaemoglobin levels in non-smoking lead workers and in controls from the same factory but not working with lead. The results were as follows:
This observation will be pursued as it opens the possibility for tests for screening workers exposed to lead.

W R LEE

Department of Occupational Health, H Dhanapal

University of Manchester

Rubino, G F, Panminerva Medica, 1962, 4, 340

Sheets, R F, et al, fournal of Clinical Investigation 1951, 30, 1272.

Waldron, H A, British fournal of Industrial Medicine, 1966, 23, 83 . 1966, 23, 83.
- Fratianne, R B, Griggs, R G, and Harris, J W,
Clinical Research, 1959, 7, 384.

Aub, J C, et al, fournal of the American Medical

Association, 1924, 83, 588.
deKrester, A J, and Waldron, H A, British fournal of Industrial Medicine, 1963, 20, 316.

deKrester, A J, and Waldron, H A, British fournal of Industrial Medicine, 1965, 22, 31

1970, 174, 23.

\section{Timing of cervical smears}

SIR,-We have never understood the reasoning behind the payment by the Department of Health and Social Security of fees for cytology tests made on women of 35 , especially in recent years when in our unit positive tests are now common at 18,20 , or 25 . The age of a patient qua precancer of the cervix is determined by her age at first coitus. Thus a general practitioner who wishes to prevent cervical cancer in his practice (with or without $f 2.30$ ) takes a test from all patients presenting for family planning or antenatal care. Moreover, if a family doctor advises all his patients at risk to take a regular Papanicolaou test they will accept this from him, while they may ignore a poster. One of us found a $95^{\circ}{ }_{0}$ acceptance of the test in his practice. In a practice of 2500 it was found that every three years his practice was completely screened, some from antenata clinics or family planning clinics and the remainder "invited" in rotation. There were seldom more than five tests per week to achieve this screening programme.

Mr Richard Simmons (8 January, p 108) challenges the DHSS advice that a test need be repeated only once in five years. How this figure was arrived at is not clear, unless it is another way of saying "That is all the money we propose to spend on cervical cancer prevention." Whether a fee is collected or not we support Mr Simmons, perhaps modifying his gap of 18 months thus:

Test 1 -negative: repeat in 1 year.

Test 2-negative: repeat in 1 year.

Test 3-negative: repeat in 2 years.

Test 4-negative: repeat in 2 years.

Thereafter every 5 years for life.

With such a mesh in the net very few precancers will slip through. Acceptability, however, is important as Dr Elizabeth McGrego of Aberdeen has emphasised. ${ }^{1}$ The more senior the patient, the more difficult it is to persuade her to take a test and return for further tests, whereas the young antenatal or family planning patient is, in practice, very co-operative.

Not only GPs are involved in cancer

Mean blood lead and carboxyhaemoglobin concentrations in workers exposed and not exposed to lead

\begin{tabular}{|c|c|c|c|c|}
\hline & No & $\begin{array}{c}\text { Mean age } \\
\text { in years } \\
\text { (range) }\end{array}$ & $\begin{array}{l}\text { Mean blood } \\
\text { lead }(\mu \mathrm{mol} / \mathrm{l}) \\
( \pm \mathrm{SD})\end{array}$ & $\begin{array}{l}\text { Mean carboxy- } \\
\text { haemoglobin } \\
\left({ }^{\prime}(1)( \pm S D)( \pm S D\right.\end{array}$ \\
\hline $\begin{array}{l}\text { Non-smoking lead workers } \\
\text { Non-smoking controls } \quad .\end{array}$ & $\begin{array}{l}23 \\
20\end{array}$ & $\begin{array}{l}35(22-60) \\
40(25-56)\end{array}$ & $\begin{array}{l}* 2.29( \pm 0.84) \\
* 1.15( \pm 0.18)\end{array}$ & $\begin{array}{l}+2.47( \pm 0.90) \\
+1.12( \pm 0.22)\end{array}$ \\
\hline
\end{tabular}

Conversion: SI to traditional units-Lead $1 \mu \mathrm{mol} / 1 \approx 20 \cdot 7 \mu \mathrm{g} / 100 \mathrm{ml}$

$t=6.40 ; \mathrm{DF}=25 ; \mathrm{P}<0.001$ prophylaxis. In a recent visit to the Middle West of the USA we noted that hospital visiting staff of all specialties were obliged to offer a Papanicolaou test or state in writing why not. A patient refusing this test was also obliged to sign a form. Whether this policy was based on the aphorism that a patient is not properly examined without a cervical test or a reflection of defensive medicine in a litigious era is hard to say. From the patient's viewpoint there is much to commend "routine Pap tests" coupled with advice as to when the test should be repeated.

H C MCLAREN A J LUCAS

Department of Obstetrics and Gynaecology, Birmingham Maternity Hospital,
Birmingham

'McGregor, J E, Proceedings of the British Society for Clinical Cytology, Aberdeen, 1974.

\section{Radiation-induced breast cancer}

SIR,-Following on the suggestion of Simon and Silverstone, ${ }^{1}$ quoted in your leading article 22 January (p 191), that repeated mammography should be avoided in fit women with a life expectancy greater than 20 years, may I suggest that it should also be avoided in breasts in which the malignant potentiality of the epithelium is known to be relatively high? The best example is the opposite breast following the development of carcinoma in one breast, a situation in which regular follow-up by mammography was once regarded as particularly indicated. The same theoretical considerations are an argument against the treatment of carcinoma of the breast by excision of the lump and radiotherapy to the remaining breast tissue.

Hythe, Kent

David Patey

'Simon, N, and Silverstone, S M, Bulletin of the New York Academy of Medicine, 1976, 52, 741.

\section{Missing tails}

SIR,-A significant number of women fitted with an intrauterine contraceptive device (IUCD) are being referred with the problem of strings being no longer visible or palpable on vaginal examination. It is common practice for such patients to be sent for a plain $x$-ray film of the abdomen to locate the IUCD. With increasing use of this method of contraception the problem will occur more frequently and needs proper assessment.

Three questions should be considered: (1) Is the IUCD still present in the patient? (2) Is the IUCD properly situated within the uterine cavity? (3) Is the patient pregnant? A routine plain film of the abdomen will answer question 1 but not 2 and is certainly contraindicated if the patient is in early pregnancy. Further, spontaneous expulsion of an IUCD unnoticed by the user is extremely uncommon. It is more useful to take posteroanterior and lateral plain films of the abdomen with a metal sound in the uterus as a marker, provided pregnancy has been excluded. On occasion passage of the sound rubs against the IUCD, aiding diagnosis. If the $x$-rays suggest that the IUCD is still within the uterine cavity no further action need be taken unless there is some indication for removal of the device. One to three months later the cervix should be visualised following a 